\title{
Critics doubt five-year-old SDI programme will ever mature
}

\section{Washington}

A NEW report on the first five years of US government funding for the Strategic Defense Initiative (SDI) concludes that industry is still not sufficiently committed to the programme to give it "unstoppable momentum"

A companion report predicts that arguments over whether the SDI systems now under development can be tested without breaching the Anti-Ballistic Missile (ABM) treaty will continue for the remainder of the Reagan presidency. A combination of these factors should leave the next president with room to manoeuvre in deciding whether to deploy the beginnings of a missile defence system.

But President Reagan, speaking last week on the fifth anniversary of his speech proposing SDI, reiterated his support for

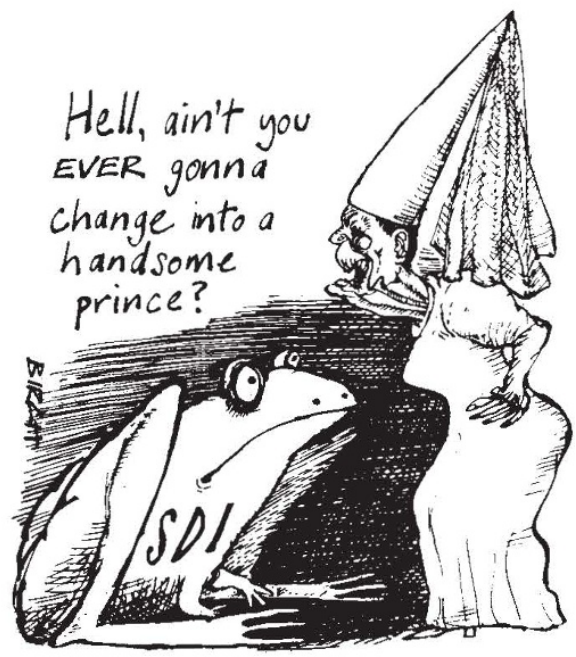

the project. He criticized Congress for restricting SDI spending, arguing that the Soviet Union is actively pursuing strategic defences of its own. Although many physicists maintain that Pentagon estimates of the technical obstacles to SDI are optimistic, Reagan said that "if anything, we overestimated the technical challenge" of SDI.

The two critical reports come from the Federation of American Scientists (FAS), a non-profit organization representing some 5,000 physical and social scientists and engineers. The first shows that SDI is more a Californian project than a US one: $\$ 6,600$ million of contract money -45 per cent of the total - is being spent there. Adding in New Mexico and Massachusetts accounts for two-thirds of all spending. Unlike the B1 bomber programme, which proved impossible to kill off, the SDI programme has not succeeded in awarding large contracts in every congressional district.

But SDI funds are very widely spread among a large number of different corporations. Many of them expect funding for other defence projects to fall in the 1990s as the military build-up ordered by President Reagan passes its peak. That may mean corporations will push hard for deployment of SDI so that they can fill their order books in the next decade. So far, however, industry has been less than enthusiastic about SDI.

SDI contracts have been awarded solely for research and have not generated big profits. These will come only if systems are ordered for deployment. But there are enormous uncertainties: several big projects have been delayed as they failed to live up to technical expectations and one, the McDonnell-Douglas project for a neutral particle beam weapon, has been cancelled outright.

Further uncertainty is added by continuing congressional opposition to tests of missile defences. The administration's 'broad' interpretation of the ABM treaty, signed by the Soviet Union and the United States in 1972 , would have permitted testing of SDI systems based on novel physical principles. But that interpretation of the treaty's language has not won acceptance in Congress. Now the administration is turning to a 'permissive' interpretation of the treaty that circumvents the ban on testing of components of a missile defence system by arguing that a component is not a component unless it could be part of a finished missile defence system.

John Pike, FAS associate director for space policy, caricatures the administration view as saying that "a car is not a car without a racing stripe". Challenges to the administration view are likely to come this year and early next year when tests fall due for the Airborne Optical System, a modified Boeing 767 carrying an infrared telescope for tracking and identifying reentry vehicles while they are still above the atmosphere. The administration will argue that because the aeroplane can stay aloft only for ten hours, and because the infrared sensor chip it carries will not have a full array of elements, the system cannot be regarded as an effective 'component' of an ABM system.

\section{CNRS outlines its biology plans to 1990}

\section{Paris}

As French political parties preparing for the May presidential elections play 'double or quits' with electoral promises, the Centre National de la Recherche Scientifique - (CNRS) - France's largest state research organization - has been taking a more sedate look at its priorities for the life sciences in the 1990s.

The life sciences division is the largest within CNRS, its 250 laboratories and 1,000 researchers swallowing half of the annual budget. It has been nine years since François Gros, François Jacob and Pierre Royer set out the last prospective for French life sciences in their report to the president of the republic. In the meantime, the face of biology has changed dramatically and the CNRS administration has now promised to revise the new programme of priorities every year.

As an overview of contemporary trends in biology, the report contains few surprises. But the authors do pinpoint particular areas of strength in French biology and (with un-Gallic candour) some weaknesses. The four major 'social and economic stakes' picked out for the 1990 s are painted with a very broad brush - health, agriculture, biotechnology and the environment. These areas, where biology can be seen to be relevant to the quality of life in France, are presented before the eight basic research themes.

France's role in isolating and describing the human immunodeficiency virus (HIV) has given a boost to immunology research.
Under the rubric of 'health', the report looks forward to progress in the study of oncogenes and the use of in vitro fertilization to study mechanisms in human reproduction and the diagnosis of genetic defects at the zygotic stage. In the fields of virology and vaccine development, the authors feel that the "small number of centres for sorting synthetic molecules" could be an obstacle to the study of antiviral molecules.

Apart from work to sequence the genomes of bacteria such as Escherichia coli and Bacillus subtilis, or of yeasts such as Saccharomyces cerevisiae, the report suggests that French laboratories could get a "ten-year lead" on US scientists by developing their efforts to sequence the genomes of "pseudo-unicellular" protista, as opposed to eukaryotes. But within enzymology, France has so far failed to exploit some of the latest techniques in X-ray crystallography, the report says.

The report is initially aimed at the CNRS administration committee and, does not address specific questions of finance. But, as a CNRS communiqué points out, one of the most daunting obstacles to future developments will be the high cost of major research programmes. Having been funded for decades with "artisan" budgets, major international programmes will require an investment "on a par with those for space or for research instruments in physics", says the pamphlet accompanying the report. Peter Coles

A. Berkaloff, R. Naquet \& J. Demaille Biologie 1990 - enjeux et problematiques. CNRS, October 1987. 